\title{
Selective involvement of BH3-only proteins and differential targets of Noxa in diverse apoptotic pathways
}

\author{
L Zhang ${ }^{1,2}$, H Lopez ${ }^{1,2}$, NM George ${ }^{1}$, X Liu $^{1}, X^{\text {Pang }}{ }^{1}$ and X Luo ${ }^{*, 1}$
}

The BH3-only proteins of the Bcl-2 family are known to mediate mitochondrial dysfunction during apoptosis. However, the identity of the critical BH3-only proteins and the mechanism of their action following treatment by diverse apoptotic stimuli remain to be fully resolved. We therefore used RNAi to screen the entire Bcl-2 family for their involvement in three major apoptotic pathways in HeLa cells. We found that Bcl-xL and Mcl-1 are major inhibitors of apoptosis induced by TNF-related apoptosis-inducing ligand (TRAIL), endoplasmic reticulum (ER) stress, and proteasome inhibition. Among the $10 \mathrm{BH} 3-\mathrm{only}$ proteins, Bid and Noxa were found to be critically involved in TRAIL-induced apoptosis, in which Noxa participates by constitutively binding to Mcl-1. Bim and Noxa were found to be necessary for ER stress-induced apoptosis, in which Noxa assisted Bim function by sequestering Mcl-1 and binding to Bcl-xL. As a critical BH3-only protein, Noxa was strongly upregulated and became associated with both Mcl-1 and Bcl-xL during apoptosis induced by proteasome inhibition. In addition, we found that Noxa became 'Mcl-1 free' following treatment by ER stress and proteasome inhibition, but not after TRAIL treatment. These results defined the critical $\mathrm{Bcl}-2$ network during apoptosis and suggested that Noxa participated in triggering mitochondrial dysfunction in multiple apoptotic pathways through distinct mechanisms.

Cell Death and Differentiation (2011) 18, 864-873; doi:10.1038/cdd.2010.152; published online 26 November 2010

Most stress signals induce apoptosis via a mitochondriadependent process, in which release of cytochrome $c$ and other apoptogenic factors from mitochondria leads to the formation of apoptosome and activation of executioner caspases. $^{1,2}$ As major regulators and effectors of this apoptotic pathway, the $\mathrm{Bcl}-2$ family proteins control the immediate steps leading to the mitochondrial dysfunction. ${ }^{3,4}$ Members of this family, sharing one or several Bcl-2 homology $(\mathrm{BH})$ domains, can be classified into the anti-apoptotic group, for example, $\mathrm{Bcl}-2, \mathrm{Bcl}-\mathrm{xL}$, and $\mathrm{Mcl}-1$, which protect the integrity of the mitochondria, and the pro-apoptotic members, which can be further divided into the multi- $\mathrm{BH}$ domain members, for example, Bax and Bak, and the BH3-only proteins, for example, Bad, Bid, Bim, Noxa, and Puma. In response to diverse apoptotic stimuli, activated $\mathrm{BH} 3-$ only proteins directly or indirectly activate the multidomain proteins Bax and Bak, which in turn homo-oligomerize and permeabilize the mitochondrial outer membrane. ${ }^{5-10}$ It is believed that the anti-apoptotic family proteins inhibit Bax/Bak activation and mitochondrial dysfunction by sequestering either the BH3-only proteins or the Bax/Bak proteins. ${ }^{7,11,12}$

Although it has been widely accepted that different apoptotic signals activate distinct $\mathrm{BH}$-only proteins, which in turn trigger the activation of the Bax/Bak proteins, in few instances, in which the triggering $\mathrm{BH} 3$-only protein has been unequivocally identified. ${ }^{13}$ For example, Bid and Bim have been identified as the triggering proteins for mitochondrial dysfunction in cell surface death receptor-mediated pathway and in endoplasmic reticulum (ER) stress-induced pathway, respectively. ${ }^{14-16}$ However, the triggering protein for mitochondrial dysfunction induced by most other apoptotic stimuli remains less clear. In addition, even in the well-characterized pathways, in which a triggering protein has been identified, it remains unclear whether other $\mathrm{BH}$-only proteins are also involved. Furthermore, for most apoptotic pathways, the exact targets of the involved $\mathrm{BH} 3-$ only proteins have not been fully defined.

We used a combination of siRNA knockdown and biochemical assays to screen the entire collections of BH3-only and anti-apoptotic $\mathrm{Bcl}-2$ proteins for their involvement in apoptosis induced by the three apoptotic stimuli mentioned above. Surprisingly, the BH3-only protein Noxa was found to be critically involved in all three pathways. Noxa is a $\mathrm{BH} 3-$ only protein identified as a transcriptional target for $p 53 .{ }^{17}$ Other studies found that Noxa can also be upregulated by DNA damage, ER stress, and proteasomal inhibition in a p53independent manner, ${ }^{18-21}$ and that overexpression of Noxa was sufficient to induce apoptosis in HeLa cells and other cell types. ${ }^{17,22}$ Recent interaction studies have demonstrated that Noxa preferentially binds to $\mathrm{Mcl}-1$, or $\mathrm{A} 1$, but not to $\mathrm{Bcl}-\mathrm{xL}$ and $\mathrm{Bcl}-2{ }^{23}$ On binding to $\mathrm{Mcl}-1$, Noxa was found to neutralize its anti-apoptotic activity, and promote the degradation of

\footnotetext{
${ }^{1}$ Eppley Institute for Research in Cancer and Allied Diseases, University of Nebraska Medical Center, Omaha, NE, USA

${ }^{*}$ Corresponding author: X Luo, Eppley Institute for Research in Cancer and Allied Diseases, University of Nebraska Medical Center, 985950 Nebraska Medical Center, Omaha, NE 68198-5950, USA. Tel: + 402559 4643; Fax: + 402559 3739; E-mail: xuluo@unmc.edu

${ }^{2}$ These authors contributed equally to this work.

Keywords: mitochondria; Bcl-2; BH3-only; apoptosis

Abbreviations: TRAIL, TNF-related apoptosis-inducing ligand; ER, endoplasmic reticulum; BH, Bcl-2 homology; TG, thapsigargin; MEF, mouse embryonic fibroblast Received 27.9.10; revised 18.10.10; accepted 19.10.10; Edited by P Bouillet; published online 26.11.10
} 
Mcl-1. ${ }^{24}$ However, as inactivation of Mcl-1 is not sufficient to induce apoptosis, ${ }^{25}$ the mechanism of how upregulated Noxa induces apoptosis remains unclear. We recently identified a DNA damage-induced interaction between Noxa and $\mathrm{Bcl}-\mathrm{xL} .{ }^{26}$ In this study, we defined the Bcl-2 network and the differential involvement of Noxa in three other apoptotic pathways.

\section{Results}

Screening for critical suppressors to apoptosis induced by TNF-related apoptosis-inducing ligand (TRAIL), ER Stress, and MG-132 among the Bcl-2-like proteins. To identify the rate-limiting steps in apoptosis pathways induced by TRAIL, ER stress, and proteasomal inhibition in HeLa cells, we first screened the anti-apoptotic Bcl-2 family proteins for critical suppressors of apoptosis. SiRNA duplexes were used to knockdown each of these proteins individually (Figure 1a). Of note, we could not detect the protein and mRNA of $A 1$ in HeLa cells. Following siRNA transfection, the cells were treated with TRAIL, thapsigargin (TG, ER stress), or MG-132 (proteasome inhibitor; Figure $1 b-d$ ), and monitored for apoptosis. The knockdown of either Bcl-xL or $\mathrm{Mcl}-1$, but not $\mathrm{Bcl}-2$, greatly sensitized the cells to TRAIL, suggesting that both $\mathrm{Bcl}-\mathrm{xL}$ and $\mathrm{Mcl}-1$ are major inhibitors of TRAIL-induced apoptosis. The elimination of $\mathrm{Bcl}-\mathrm{xL}$, but not any other members, greatly sensitized cells to $\mathrm{TG}$ treatment, suggesting that $\mathrm{Bcl}-\mathrm{xL}$ is a major inhibitor of TG-induced apoptosis (Figure 1c). The knockdown of Mcl-1, or to a lesser extent, $\mathrm{Bcl}-\mathrm{xL}$, but not others, sensitized cells to MG-132 treatment, suggesting that $\mathrm{Bcl}-\mathrm{xL}$ and $\mathrm{Mcl}-1$, especially $\mathrm{Mcl}-1$, are major rate-limiting proteins in this pathway (Figure 1d).

We next investigated the combined role of $\mathrm{Bcl}-\mathrm{xL}$ and $\mathrm{Mcl}-1$ in the survival of HeLa cells. As shown in Figure 1e, the simultaneous knockdown of these two proteins resulted in potent apoptosis without any apoptotic stimulus, indicating that $\mathrm{Bcl}-\mathrm{xL}$ and $\mathrm{Mcl}-1$ together constitute a major survival mechanism in HeLa cells. These results also suggest that inactivation of both $\mathrm{Bcl}-\mathrm{xL}$ and $\mathrm{Mcl}-1$ may be a common rate-limiting step during apoptosis induced by multiple apoptosis pathways.
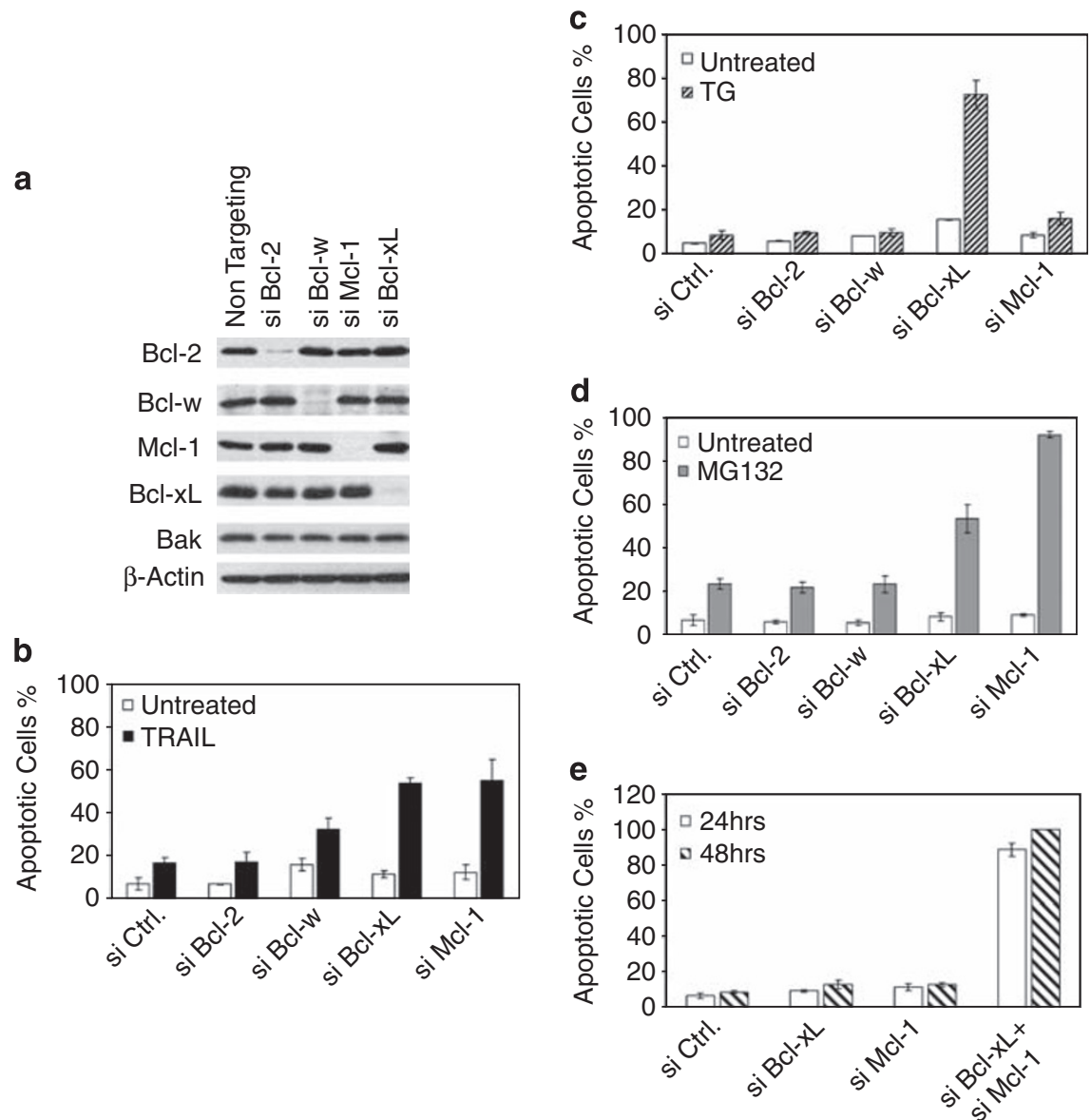

Figure 1 Selective involvement of anti-apoptotic Bcl-2 family proteins in TRAIL-, TG-, and MG-132-mediated apoptotic pathway. (a) HeLa cells were transfected with the indicated pools of siRNA duplexes. Following siRNA transfection, cell lysates were generated in EBC buffer and subjected to western blot analysis. (b) At $60 \mathrm{~h}$ after siRNA transfection, HeLa cells were treated with TRAIL $(10 \mathrm{ng} / \mathrm{ml})$ for $3 \mathrm{~h}$, and apoptosis was quantified by Hoechst staining. (c) Similar to $\mathbf{b}$, siRNA transfected HeLa cells were treated with thapsigargin (TG, $5 \mu \mathrm{M})$ for $3 \mathrm{~h}$ before apoptosis was quantified by Hoechst staining. (d) Similar to $\mathbf{b}$, siRNA transfected HeLa cells were treated with MG-132 $(2 \mu \mathrm{M})$ for $12 \mathrm{~h}$ before apoptosis was quantified by Hoechst staining. (e) At $24 \mathrm{~h}$ or $48 \mathrm{~h}$ following siRNA transfection by the indicated siRNA duplexes, apoptosis was quantified by Hoechst staining. The results from $(\mathbf{b}-\mathbf{e})$ are mean \pm S.D. from at least three independent siRNA transfections 
Identification of Bid and Noxa as critical BH3-only proteins involved in TRAIL-induced apoptosis. Next, we examined the involvement of the $\mathrm{BH} 3$-only proteins in TRAIL-induced apoptosis by a similar siRNA screening. The knockdown of the target proteins was verified either by western blot analysis or by RT-PCR (Figure 2a). As expected, although knockdown of most of $\mathrm{BH}$-only proteins individually had little effect, the knockdown of Bid essentially abolished TRAIL-induced apoptosis (Figure 2b). Unexpectedly, the knockdown of Noxa also conferred strong inhibition of Bak activation and apoptosis (Figure $2 \mathrm{~b}$ and Supplementary Figure S1). Of note, we also verified the involvement of Noxa in TRAIL-induced apoptosis in $\mathrm{H} 460$ cells (Supplementary Figure S2).

To investigate the mechanism of involvement of Bid and Noxa in TRAIL-induced apoptosis, we examined the changes of these proteins following TRAIL treatment by western blot (Figure 2c). Although no changes were observed for Bad, Bim, Noxa, Mcl-1, and Bcl-xL, Bid was cleaved into tBid after $3 \mathrm{~h}$ of TRAIL treatment. As both Bcl-xL and $\mathrm{Mcl}-1$ are critically involved in suppressing apoptosis induced by TRAIL, we examined the potential interaction between the involved $\mathrm{BH}$ only proteins with $\mathrm{Bcl}-\mathrm{xL}$ and $\mathrm{Mcl}-1$ after TRAIL treatment. Two stable cell lines were generated that overexpress a polyhistidine-tagged Bcl-xL (Supplementary Figure S3) and a similarly tagged $\mathrm{Mcl}-1$, respectively. Following TRAIL treatment, the cell extracts were passed through nickel affinity column to examine for the endogenous $\mathrm{BH} 3-$ only proteins associated with either $\mathrm{Bcl}-\mathrm{xL}$ or $\mathrm{Mcl}-1$. Although Bad and Bim bound to $\mathrm{Bcl}-\mathrm{xL}$ constitutively, $\mathrm{tBid}$ was generated and bound to $\mathrm{Bcl}-\mathrm{xL}$ after $3 \mathrm{~h}$ (Figure $2 \mathrm{~d}$ ). In contrast, no Noxa was found associated with $\mathrm{HiS}_{9}-\mathrm{Bcl}-\mathrm{xL}$ before or after TRAIL treatment. Using $\mathrm{His}_{9}-\mathrm{Mcl}-1$ cells, we found that while Noxa and Bim constitutively bound to $\mathrm{Mcl}-1$, tBid associated with $\mathrm{Mcl}-13 \mathrm{~h}$ after TRAIL treatment (Figure 2e), whereas Bad did not show any association with $\mathrm{Mcl}-1$, consistent with differential binding of $\mathrm{BH} 3-$ only proteins to $\mathrm{BCl}-\mathrm{xL}$ and $\mathrm{Mcl}-1 .{ }^{23}$ Thus, although tBid is the triggering protein in this pathway, Noxa is passively involved by constitutively binding to endogenous $\mathrm{Mcl}-1$, inhibiting its anti-apoptotic activity. Indeed, at least a fraction of endogenous $\mathrm{Mcl}-1$ is associated with endogenous Noxa (Figure 5b), and the knockdown of Noxa increased the concentration of active Mcl-1 (Supplementary Figure S4), which was able to sequester more active Bak (Supplementary Figure S5).

Bim and Noxa are critical BH3-only proteins during ER stress-induced apoptosis. SiRNA against each of the 10 known BH3-only proteins was transfected into HeLa cells individually. Although knockdown of most $\mathrm{BH} 3-$ only proteins individually failed to show any effect, the knockdown of either Bim or Noxa showed strong protection against TG-induced Bak activation and apoptosis (Figure $3 a$ and Supplementary Figure S6). Consistent with previous studies, we observed an a

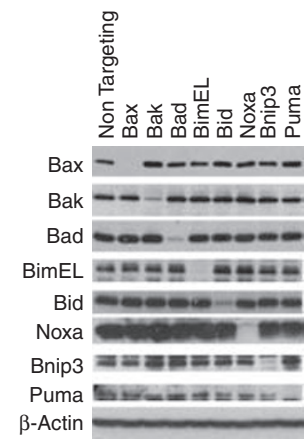

c

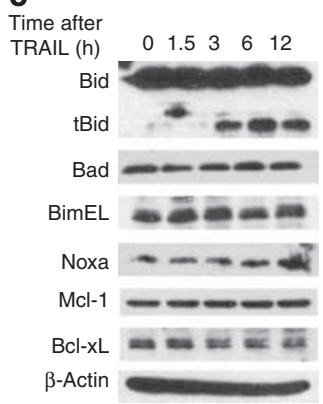

d

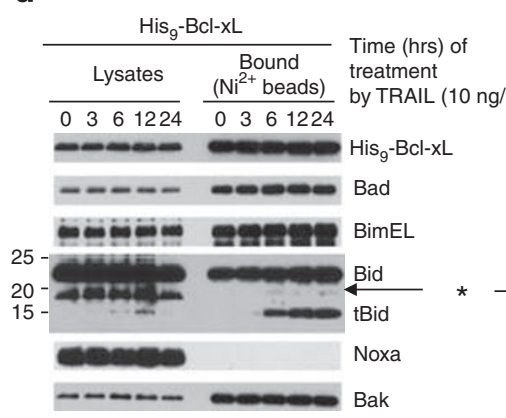

b

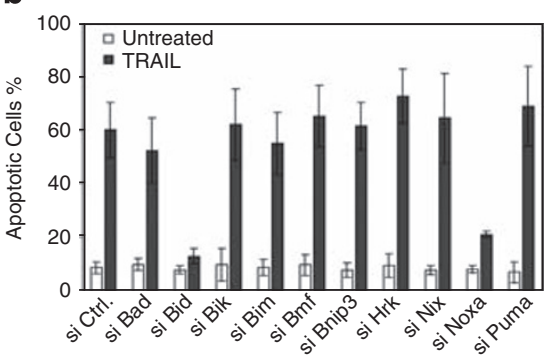

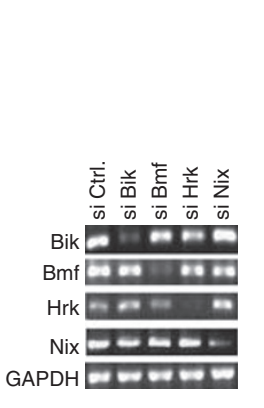

b

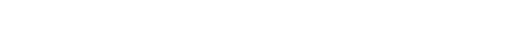

e

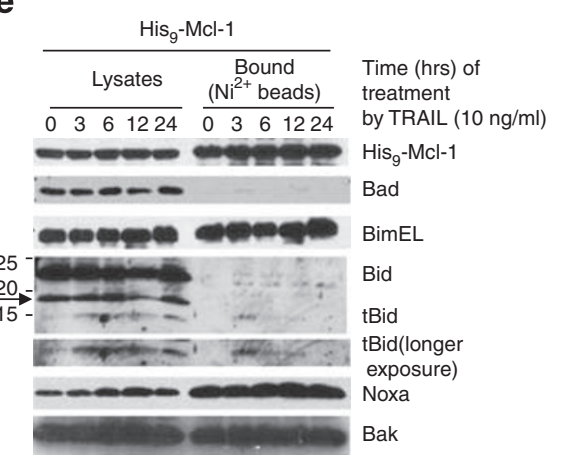

Figure 2 Involvement of Bid (or tBid) and Noxa in TRAIL-induced apoptosis. (a) At $60 \mathrm{~h}$ following siRNA transfection, the six proteins on the left were examined by western blot with their respective antibodies. The mRNAs of four genes on the right were amplified by RT-PCR and loaded on agarose gel. (b) At $60 \mathrm{~h}$ after siRNA transfection, HeLa cells were treated with TRAIL $(10 \mathrm{ng} / \mathrm{ml})$ for $6 \mathrm{~h}$ before apoptosis was quantified by Hoechst staining. The results are the mean \pm S.D. from at least three independent siRNA transfections. (c) HeLa cell lysates were generated by EBC buffer at different time points following TRAlL treatment and analyzed by western blot. (d) HeLa cells overexpressing Bcl-xL with a $9 \times$ His tag ( $\mathrm{His}_{9}-\mathrm{Bcl}-\mathrm{xL}$ ) were treated with TRAlL for the indicated times and harvested in EBC buffer (as described in Figure 1). The cell lysates were subjected to Nickel beads pulldown, and analyzed by western blot. *A non-specific protein. (e) His 9 -Mcl-1 cells were treated with TRAIL for the indicated lengths of time. Similar to $\mathrm{d}$, the proteins bound to the $\mathrm{Ni}^{2+}$ beads were analyzed by western blot 
a

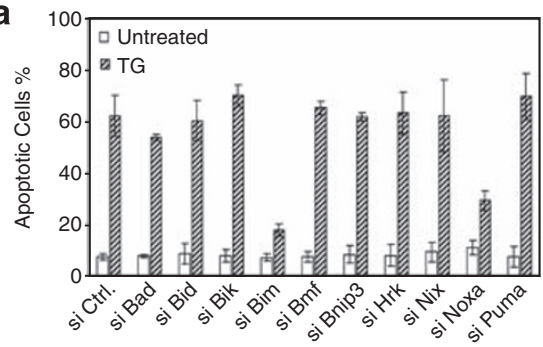

b Time (hrs) $0 \quad 3 \quad 61224$

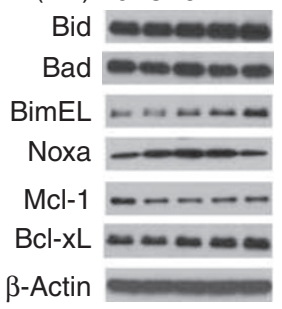

C
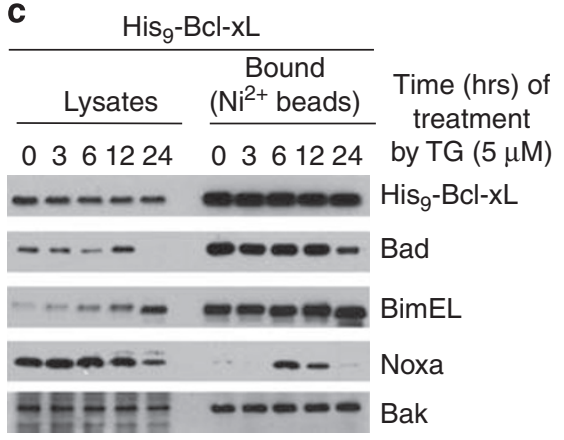

d

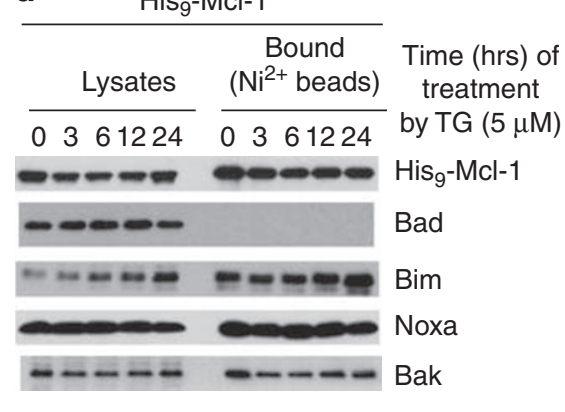

Figure 3 Involvement of Bim and Noxa in TG-induced apoptosis. (a) At $60 \mathrm{~h}$ after siRNA transfection, HeLa cells were treated with TG $(5 \mu \mathrm{M})$ for $16 \mathrm{~h}$ before apoptosis was quantified by Hoechst staining. The results are the mean \pm S.D. from at least three independent siRNA transfections. (b) HeLa cell lysates were generated by EBC buffer at different time points following TG treatment and analyzed by western blot. (c and d) HeLa cells overexpressing Hisg-Bcl-xL (c) or Hisg-Mcl-1 (d) were treated with TG for the indicated times and harvested in EBC buffer. Cell lysates were subjected to nickel beads pulldown. The bound proteins were eluted with imidazole and analyzed by western blot

upregulation and increase of mobility of BimEL (most likely due to de-phosphorylation), and a modest upregulation of Noxa following TG treatment (Figure 3b). ${ }^{14,27}$

Next, we examined the binding of the relevant $\mathrm{BH} 3-$ only proteins to either $\mathrm{His}_{9}-\mathrm{Bcl}-\mathrm{xL}$ or $\mathrm{His}_{9}-\mathrm{Mcl}-1$ following TG treatment. As expected, a gradual increase of Bim bound to $\mathrm{Bcl}-\mathrm{xL}$ was observed. Surprisingly, a Noxa/Bcl-xL interaction was detected after $6 \mathrm{~h}$ (Figure 3c). This TG-induced Noxa/ $\mathrm{Bcl}-\mathrm{xL}$ interaction was also confirmed in cell extracts generated in CHAPS (Supplementary Figure S7). In $\mathrm{His}_{9}-$ Mcl-1cells, while Bim increased its binding to Mcl-1 following TG treatment, Noxa constitutively bound to $\mathrm{Mcl}-1$ (Figure 3d). These results suggest that while Bim serves as the major triggering proteins for mitochondrial dysfunction, Noxa may also be actively involved by binding to and inactivating endogenous $\mathrm{Bcl}-\mathrm{xL}$ and $\mathrm{Mcl}-1$ in this pathway.

Noxa as a major BH3-only protein involved in proteasome inhibition-induced apoptosis. SiRNA screening was used to examine the involvement of the BH3-only proteins in proteasomal inhibition-induced apoptosis. The knockdown of Noxa, but not any of the other nine known BH3-only proteins, potently inhibited MG-132-induced apoptosis, suggesting that Noxa is a major BH3-only protein required for $M G-132$-induced Bak activation and apoptosis (Figure 4a and Supplementary Figure S8). As expected, while Bid, Bad, Bim, and Bcl-xL remained unchanged, we observed a strong increase of both Noxa and Mcl-1 after MG132 treatment. This increase is consistent with a transcriptional upregulation of Noxa and a blockade of degradation of $\mathrm{Mcl}-1$ due to proteasomal inhibition. ${ }^{25}$
We next examined the potential interaction between the BH3-only proteins and $\mathrm{Bcl}-\mathrm{xL}$ or $\mathrm{Mcl}-1$ using $\mathrm{His}_{9}-\mathrm{Bcl}-\mathrm{xL}$ or His $-\mathrm{Mcl}-1$ cells. Surprisingly, while Bad and Bim bound $\mathrm{Bcl}-\mathrm{xL}$ constitutively, Noxa became associated with $\mathrm{Bcl}-\mathrm{xL}$ following MG-132 treatment. This MG-132-induced Noxa/ $\mathrm{Bcl}-\mathrm{xL}$ interaction was also confirmed in cell extracts generated in CHAPS (Supplementary Figure S9). In the pulldown analysis with $\mathrm{His}$-Mcl-1, while Bad did not show any binding, Bim constitutively bound $\mathrm{Mcl}-1$. A steady increase of binding of Noxa to Mcl-1 was observed, presumably due to a concomitant increase of both $\mathrm{His}_{9}-\mathrm{Mcl}-1$ and Noxa. These results suggest that Noxa is primarily responsible for MG-132induced Bax/Bak activation and apoptosis by inactivating both $\mathrm{Mcl}-1$ and $\mathrm{Bcl}-\mathrm{xL}$.

Generation of 'Mcl-1 free' Noxa and its binding to $\mathrm{Bcl}-\mathrm{xL}$ at the endogenous level following TG or MG-132, but not TRAIL treatment. The apparent involvement of Noxa in all three apoptotic pathways examined prompted us to investigate the status of endogenous Noxa during apoptosis induced by these treatments. As shown in Figures 2, 3, and 4 , before any treatment, Noxa is associated with Mcl-1. We, therefore, examined the availability of 'Mcl-1 free' Noxa following these treatments. In our recent study, we developed an assay to detect the potential excess amount of Noxa free from endogenous $\mathrm{Mcl}-1 .{ }^{26}$ In this assay, at different time points following treatment by different stimuli, HeLa cells extracts were generated and incubated with GST-Mcl-1 or GST at $4{ }^{\circ} \mathrm{C}$ to detect any free Noxa that is not associated with the endogenous $\mathrm{Mcl}-1$. GST-Mcl-1 was unable to pulldown any Noxa from lysates from untreated or 
a

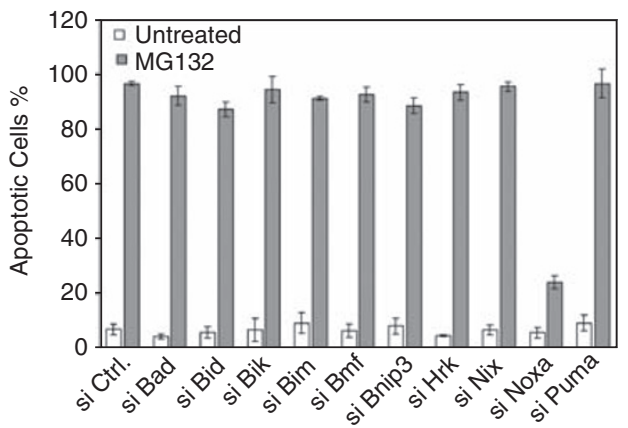

b

$\begin{array}{llllll}0 & 3 & 6 & 12 & 24 & \text { Time (hrs) }\end{array}$

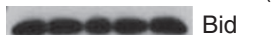

- Bad

Eas ateres BimEL

Noxa

Mcl-1

$-\infty=0$ Bcl-xL

$\beta$-Actin
C

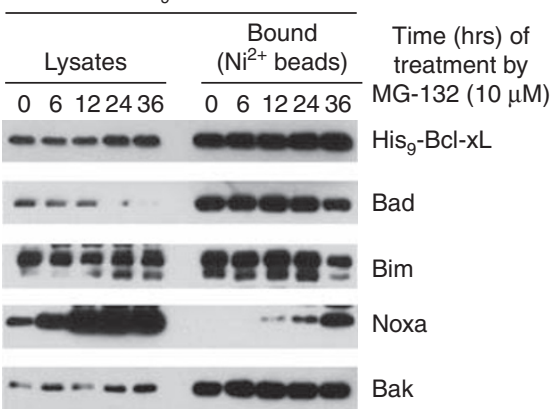

d $\quad \mathrm{His}_{9}-\mathrm{Mcl}-1$

\begin{tabular}{|c|c|c|}
\hline Lysates & $\begin{array}{c}\text { Bound } \\
\left(\mathrm{Ni}^{2+} \text { beads }\right)\end{array}$ & $\begin{array}{l}\text { Time (hrs) of } \\
\text { treatment by }\end{array}$ \\
\hline $0 \quad 6122436$ & $\begin{array}{llll}0 & 6 & 1224 & 36\end{array}$ & MG-132 (10 $\mu \mathrm{M})$ \\
\hline nese & recerses & $\mathrm{His}_{9}-\mathrm{Mcl}-1$ \\
\hline 50 & & Bad \\
\hline & $\operatorname{en}-$ & Bim \\
\hline 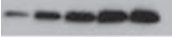 & $---\infty$ & Noxa \\
\hline$-\infty-m-$ & $-m-5-$ & Bak \\
\hline
\end{tabular}

Figure 4 Involvement of Noxa in MG-132-induced apoptosis. (a) At $60 \mathrm{~h}$ after siRNA transfection, HeLa cells were treated with MG-132 (10 $\mu \mathrm{M})$ for $16 \mathrm{~h}$ before apoptosis was quantified by Hoechst staining. The results are the mean \pm S.D. from at least three independent siRNA transfections. (b) HeLa cell lysates were generated by EBC buffer at different time points following MG-132 treatment and analyzed by western blot. (c and d) HeLa cells overexpressing His $s_{9}-\mathrm{Bcl}-\mathrm{xL}$ (c) or His $\mathrm{H}_{9}-\mathrm{Mcl}-1$ (d) were treated with TG for the indicated times and harvested in EBC buffer. Cell lysates were subjected to nickel beads pulldown. The bound proteins were eluted with imidazole and analyzed by western blot

a
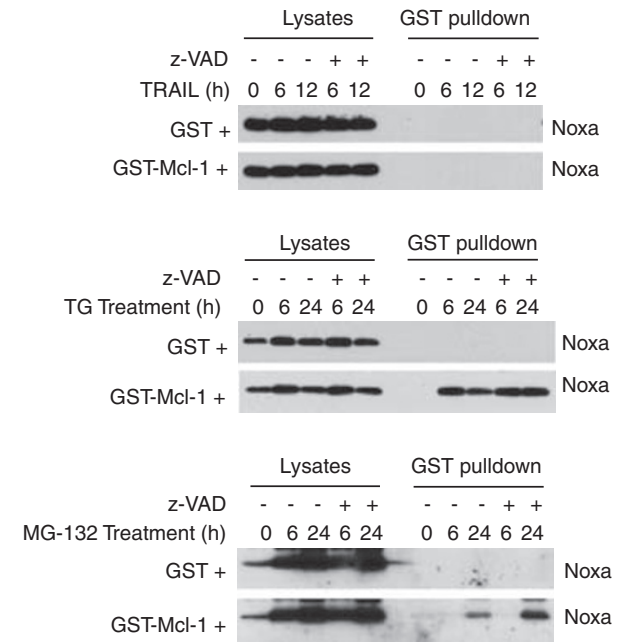

b

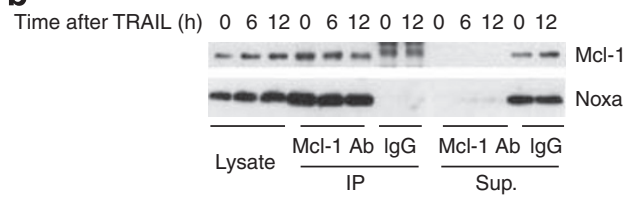

Time after TG (h) 0062406240240624024

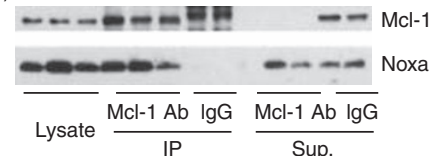

Time after MG-132 (h) $0 \quad 62406240240624024$

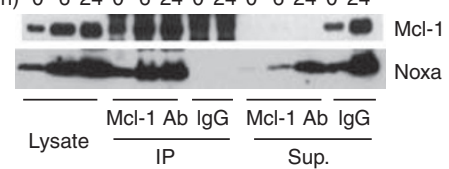

Figure 5 Generation of 'Mcl-1 free' Noxa during apoptosis induced by TG and MG-132. HeLa cells were treated with TRAIL (10 ng/ml), TG $(5 \mu \mathrm{M})$, or MG-132 (10 $\mu \mathrm{M})$ in the presence or absence of the caspase inhibitor Z-VAD $(20 \mu \mathrm{M})$. (a) Whole-cell lysates $(1 \mathrm{mg})$ generated in EBC buffer were mixed with either GST (100 nM) or GST-Mcl-1 $(100 \mathrm{nM})$ for $1 \mathrm{~h}$ before being subjected to GST pulldown. Glutathione beads were eluted by boiling in SDS loading solution and subjected to SDS-PAGE. Western blots were probed by anti-Noxa antibody. (b) Whole-cell extracts $(1 \mathrm{mg})$ were subjected to immunoprecipitation by either Mcl-1 antibody or by control lgG. The lysates, immunoprecipitate, and the supernatant after immunoprecipitation were loaded onto SDS-PAGE. Western blots were probed by anti-Noxa and anti-Mcl-1 antibodies

TRAIL-treated cells, indicating that Noxa remained associated with endogenous $\mathrm{Mcl}-1$ (Figure $5 \mathrm{a}$ ). In contrast, $6 \mathrm{~h}$ after TG treatment, GST-Mcl-1 was able to pulldown a significant amount of endogenous Noxa, indicating that Noxa became free from endogenous Mcl-1 during TG treatment. Similarly, at later time points after MG-132 treatment, we observed the appearance of 'Mcl-1 free' Noxa. However, because of the superior affinity between $\mathrm{Mcl}-1$ and Noxa as 
a

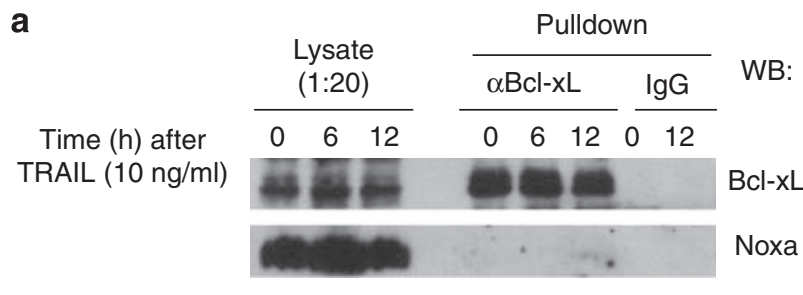

b

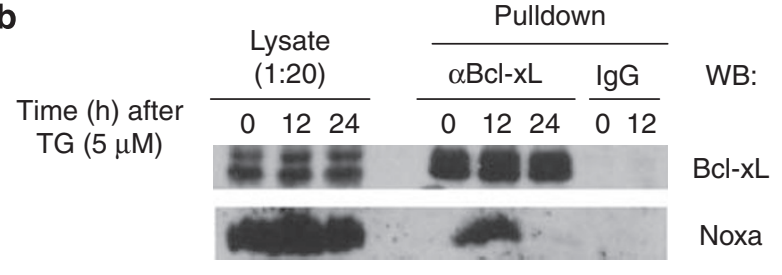

C

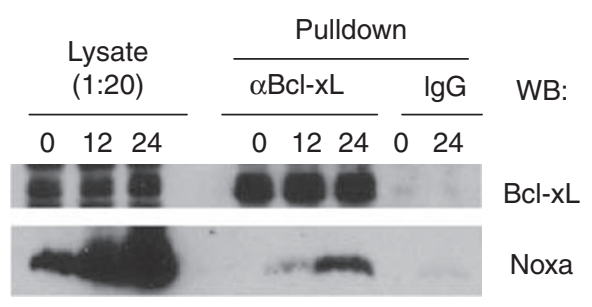

Figure 6 Endogenous interaction between Noxa and Bcl-xL following TG or MG-132, but not TRAIL treatment. HeLa cells were treated with (a) TRAIL (10 ng/ml), (b) TG $(5 \mu \mathrm{M})$, or (c) MG-132 $(10 \mu \mathrm{M})$ for the indicated time points. Cells lysates were then subjected to immunoprecipitation using Bcl-xL antibody or IgG control antibody as described in the Material and Methods. The lysates and immunoprecipitates were loaded onto SDS-PAGE. Western blots were probed by anti-Noxa and anti-Bcl-xL antibodies

compared with that between $\mathrm{Bcl}-\mathrm{xL}$ and Noxa, we would expect that GST-Mcl-1 may compete Noxa away from Bcl-xL even from the $\mathrm{Bcl}-\mathrm{xL} / \mathrm{Noxa}$ complex in the in vitro association assay carried out at $4{ }^{\circ} \mathrm{C}{ }^{26}$ The status of Noxa after apoptotic stimulation was also examined by immunoprecipitation by an antibody against Mcl-1. As shown in Figure 5b, in extracts depleted of Mcl-1, we were able to detect Noxa after TG and MG-132 treatments, but not after TRAIL treatment. These results show the generation of 'Mcl-1 free' Noxa during TG- and MG-132-, but not TRAIL-induced apoptosis.

Next, we tested whether the induced Noxa/Bcl-xL interaction after TG or MG-132 can occur at the endogenous level. HeLa cells were treated with TRAIL, TG, or MG-132, and harvested at different time points after each treatment. The cell extracts were subjected to immunoprecipitation by either a control IgG or an antibody against Bcl-xL. As shown in Figure 6, Noxa was found associated with $\mathrm{Bcl}-\mathrm{xL}$ following treatment by TG or MG-132, but not by TRAIL, suggesting that Noxa may be able to neutralize endogenous $B c l-x L$ in an inducible manner.

Apoptosis in HeLa cells induced by overexpression of Noxa. The generation of 'Mcl-1 free' Noxa and the induced Noxa/Bcl-xL interaction following either TG or MG-132 treatment prompted us to examine the effects of Noxa upregulation in HeLa cells. Tetracycline inducible cell lines of wild-type Noxa, a $\mathrm{BH} 3$ domain mutant, and GFP were established (Figure 7a). After induction, cell extracts were generated and subjected to immunoprecipitation by either the control IgG or the Bcl-xL antibody. As expected, the $\mathrm{Bcl}-\mathrm{xL}$ antibody was able to pulldown the wild-type Noxa, but not the $\mathrm{BH} 3$ mutant, suggesting the $\mathrm{BH} 3$ dependence of this interaction (Figure 7b). Furthermore, as shown in Figure 7c, the induced expression of Noxa, but not its BH3 mutant or GFP caused significant apoptosis in HeLa cells. To further determine the specificity of apoptosis induced by Noxa upregulation, we established HeLa cells that inducibly express mouse Bad (Figure 7d). In contrast to Noxa induction, the inducible expression of Bad failed to induce apoptosis in HeLa cells. However, the induction of Bad greatly sensitized the cells to TRAIL, TG, or MG-132 treatment (Figure $7 \mathrm{e}-\mathrm{g}$ ). As inactivation or neutralization of both $\mathrm{Bcl}-\mathrm{xL}$ and $\mathrm{Mcl}-1$ is necessary for apoptosis (Figure 1e), these results support the notion that, while Bad targets mostly $\mathrm{Bcl}-\mathrm{xL}$, Noxa is able to target both $\mathrm{Mcl}-1$ and $\mathrm{Bcl}-\mathrm{xL}$ in vivo.

\section{Discussion}

In this study, we used a loss-of-function approach to systematically screen the $\mathrm{Bcl}-2$ family proteins for their critical involvement in mitochondria-dependent apoptosis in HeLa cells. Combined with interaction and functional studies, this approach enabled us to define the unique Bcl-2 networks necessary for apoptosis induced by DNA damage in our recent study ${ }^{26}$ and by three other major apoptosis stimuli in this study. Importantly, our results suggest the involvement of selective Bcl-2 networks and differential mechanisms of how $\mathrm{BH} 3-$ only protein Noxa in triggering mitochondrial dysfunction in response to different apoptotic stimuli (Figure 8).

Distinct Bcl-2 network in a given cell is responsible for apoptosis induced by different stimuli. By screening the anti-apoptotic $\mathrm{Bcl}-2$ members, we found $\mathrm{Bcl}-\mathrm{xL}$ and $\mathrm{Mcl}-1$ are two major components of the cell survival machinery in these cells. This result is consistent with a synergy in apoptosis induction between Bad and Noxa, which preferentially target $\mathrm{Bcl}-\mathrm{xL}$ and $\mathrm{Mcl}-1$, respectively. ${ }^{23}$ Similarly, ABT-737, a BH3 peptidomimetic compound that most closely resembled Bad $\mathrm{BH} 3$, showed strong synergistic killing together with a loss of $\mathrm{Mcl}-1,{ }^{28,29}$ suggesting that apoptosis signaling pathways converge on the functional inactivation of both $\mathrm{Bcl}-\mathrm{xL}$ and $\mathrm{Mcl}-1$. The lack of effect of Bcl-2 knockdown on apoptosis (Figure 1) is consistent with an earlier finding in HeLa and mouse embryonic fibroblasts (MEFs) ${ }^{24}$ It is possible that the endogenous $\mathrm{Bcl}-2$ is differentially inhibited in HeLa cells or MEFs, although overexpression of $\mathrm{Bcl}-2$ was able to suppress apoptosis in HeLa cells (Supplementary Figure S3).

It has been well accepted that the mitochondrial pathway is initiated during cell surface death receptor-mediated apoptosis after the generation of tBid by caspase- $8 .^{15,16}$ The involvement of Noxa suggests that at least in some cells, generation of tBid alone is not sufficient to initiate the mitochondrial pathway. Similarly, it is somewhat surprising that knockdown of Noxa impeded ER stress-induced apoptosis, indicating that although $\mathrm{Bim}$ is a potent apoptosis inducer, it is not sufficient for apoptosis in certain cells. These 
a

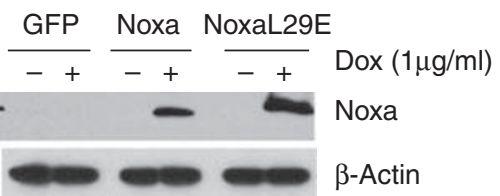

b
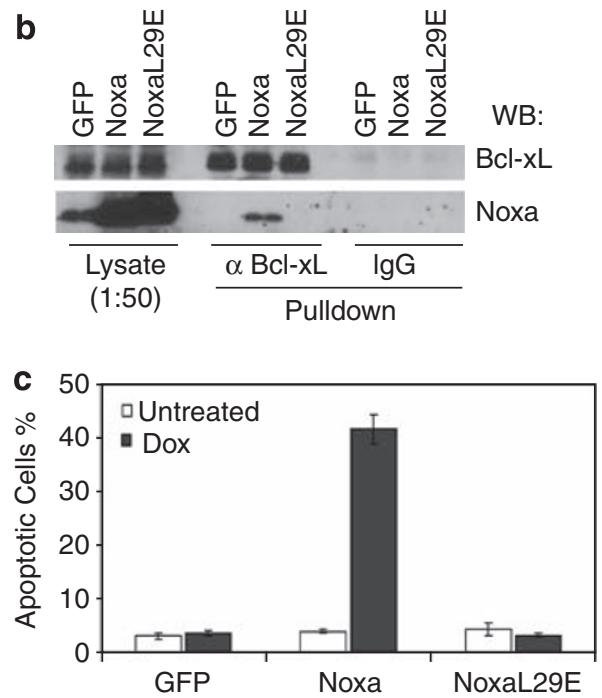
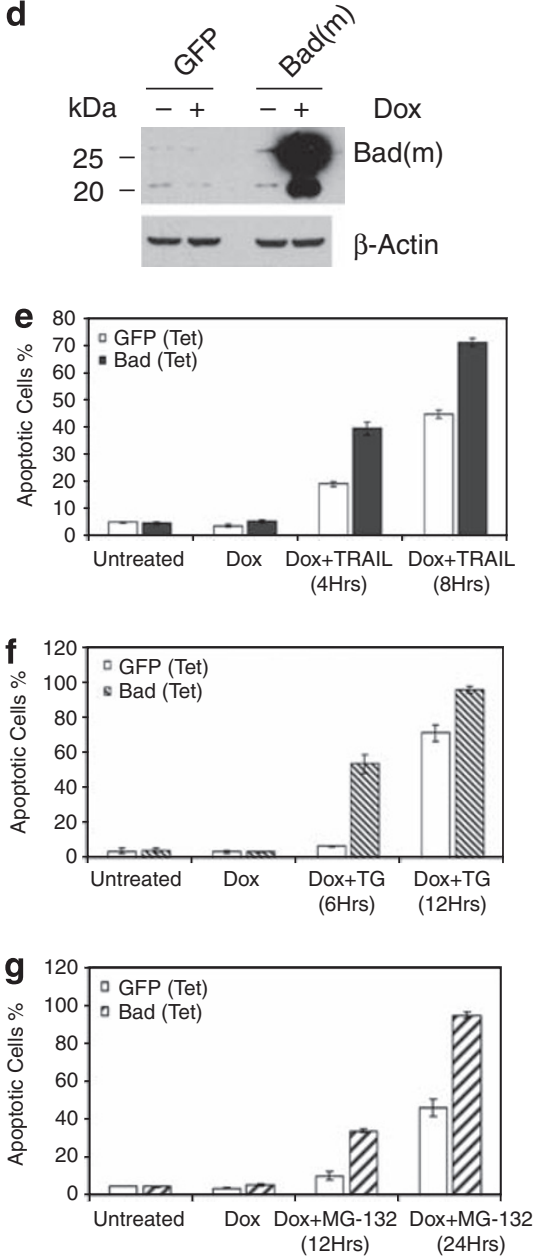

Figure 7 Induction of apoptosis in HeLa cells by overexpressing Noxa. (a) Western blot analysis showing expression for Noxa and Noxa L29E mutant $24 \mathrm{~h}$ after Dox $(1 \mu \mathrm{g} / \mathrm{ml})$ induction. (b) Endogenous Bcl-xL binds overexpressed Noxa but not Noxa L29E mutant. Expression of GFP, Noxa, and NoxaL29E was induced for $16 \mathrm{~h}$ using Dox $(1 \mu \mathrm{g} / \mathrm{ml})$, followed by immunoprecipitation using either Bcl-xL antibody or lgG control antibody. The lysates and immunoprecipitates were loaded onto SDS-PAGE. Western blots were probed by anti-Noxa and anti-Bcl-xL antibodies. (c) Noxa overexpression is sufficient to induce cell death in HeLa cells. Expression of GFP, wild-type Noxa, or NoxaL29E mutant was induced using Dox $(1 \mu \mathrm{g} / \mathrm{ml})$. Apoptosis was quantified by Hoechst staining $24 \mathrm{~h}$ after induction. The results are mean \pm S.D. from at least three independent experiments. (d) Western blot analysis showing levels of Bad (mouse) overexpression $24 \mathrm{~h}$ after Dox $(1 \mu \mathrm{g} / \mathrm{ml})$ induction. (e-g) Expression of GFP or Bad was induced in HeLa cells for $24 \mathrm{~h}$ using Dox $(1 \mu \mathrm{g} / \mathrm{ml})$, cells were then treated with TRAIL $(10 \mathrm{ng} / \mathrm{ml}, \mathbf{e}), \mathrm{TG}(5 \mu \mathrm{M}, \mathrm{f})$, or MG-132 $(10 \mu \mathrm{M}, \mathbf{g})$ and cell death was assayed at the indicated time points

results highlight the critical role of in vivo cooperativity among the BH3-only proteins during apoptosis.

Noxa constitutively suppresses Mcl-1 function before apoptotic signaling. The role of Noxa in TRAIL pathway is unexpected because Noxa is normally considered an inducible $\mathrm{BH} 3-$ only protein that functions only when it is upregulated. ${ }^{21}$ It seems that Noxa is involved in TRAILinduced apoptosis through $\mathrm{Mcl}-1$, a potent inhibitor of this pathway. As Noxa was found to be associated with Mcl-1 constitutively, it is reasonable to suggest that Noxa functions as a constitutive inhibitor for $\mathrm{Mcl}-1$, which is known to sequester both tBid and Bak. ${ }^{30,31}$ The elimination of Noxa would, therefore, effectively cause an increase of free/active Mcl-1, which in turn inhibits mitochondrial damage and apoptosis at least in part by sequestering more active Bak (Supplementary Figures S4 and S5). Consistent with this notion, knockdown of $\mathrm{Mcl}-1$ by siRNA greatly sensitized
HeLa cells to TRAIL (Figure 1). It is interesting that among the $10 \mathrm{BH} 3$-only proteins, only Noxa was identified as a helper for tBid. It can be speculated that other $\mathrm{BH}$-only proteins, for example Bad, BimEL, or Puma, are not involved because of the to differential compartmentalization, lower in vivo affinity for $\mathrm{Mcl}-1$, lower in vivo concentrations, or differential post-translational modification in this setting.

Noxa as an induced inactivator of Bcl-xL in ER stressand proteasomal inhibition induced-apoptosis. Following ER stress and MG-132 treatment, Noxa became 'Mcl-1 free' and associated with Bcl-xL. What is the mechanism of this induced interaction? In response to ER stress, Noxa level seemed to have a modest increase in HeLa cells (Figure $3 \mathrm{~b}$ ). In addition, a modest downregulation of Mcl-1 was also observed (Figure $3 b$ ). Both changes would be expected to help generate 'Mcl-1 free' Noxa, which may interact with endogenous Bcl-xL (Figure 6). Similarly, 'Mcl-1 

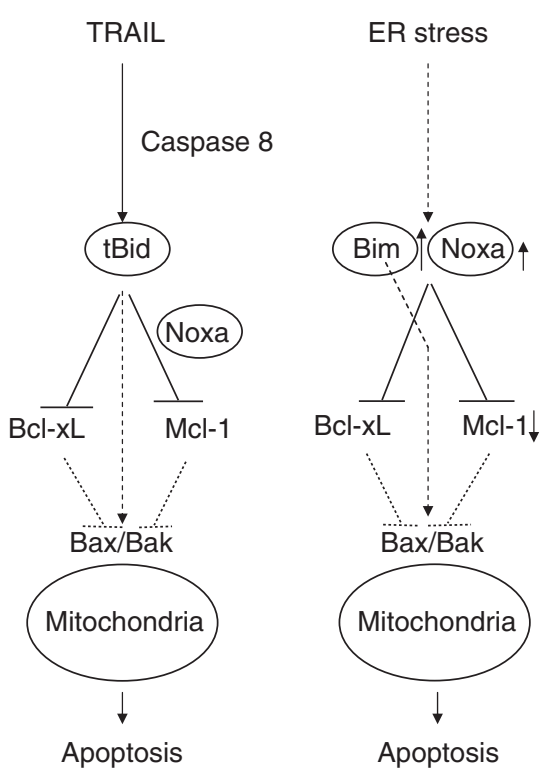

Proteasome Inhibition

Figure 8 Model for selective involvement of BH3-only Proteins in multiple apoptosis pathways. Bcl-xL and Mcl-1 are the major inhibitors of apoptosis induced by TRAIL, TG, and MG-132 in HeLa cells. The neutralization of both Mcl-1 and $\mathrm{Bcl}-\mathrm{xL}$ is sufficient to induce apoptosis. During TRAIL-induced apoptosis, tBid is the major trigger for mitochondrial dysfunction by neutralizing both Mcl-1 and Bcl-xL, and/or directly activating Bax/Bak. Noxa facilitates TRAIL-induced apoptosis by constitutively sequestering a fraction of Mcl-1. During ER stress-induced apoptosis, Bim becomes upregulated and is the major triggering protein by binding to $\mathrm{Bcl}-\mathrm{xL}$ and Mcl-1, and/or Bax/Bak. Noxa facilitates apoptosis triggering by sequestering Mcl-1 and binding to Bcl-xL following ER stress. During proteasome inhibition, Noxa becomes upregulated and has a major role in triggering mitochondrial dysfunction by binding to and inactivating both $\mathrm{Mcl}-1$ and $\mathrm{Bcl}-\mathrm{xL}$

free' Noxa was generated during MG-132 treatment, presumably because of a continuous increase of level of Noxa, exceeding that of Mcl-1.

As our results do not exclude the possibility that multiple $\mathrm{BH} 3-$ only proteins, in addition to Noxa and Bim, are involved in neutralizing $\mathrm{Bcl}-\mathrm{xL}$, we also screened for $\mathrm{BH} 3$-only proteins that inducibly interact with the $\mathrm{Bcl}-\mathrm{xL}$ following TG or MG-132 treatment (Supplementary Figure S10A). Interestingly, Bmf and Puma showed increased binding to $\mathrm{His}_{9}-\mathrm{Bcl}-\mathrm{xL}$ after TG treatment. Therefore, we carried out the double knockdown of Bmf and Puma, and tested its effect on TG-induced apoptosis in HeLa cells (Supplementary Figures S10B and C). Similar to the single knockdowns, the double knockdown did not have any effect on apoptosis, making a simultaneous involvement of these two proteins in TG-induced apoptosis unlikely. Similarly, Bik and tBid also showed an increase in binding to His $-\mathrm{Bcl}-\mathrm{xL}$ following MG-132 treatment (Supplementary Figure S11A). However, the double knockdown of Bik and Bid failed to block apoptosis (Supplementary Figures S11B and $C$ ), suggesting that the combined actions of these two proteins are not necessary for MG-132-induced apoptosis.

What is the consequence of the induced interaction between Noxa and Bcl-xL? Although mouse Noxa has originally been reported to interact with $\mathrm{Bcl}-\mathrm{xL}$ when both Noxa and $\mathrm{Bcl}-\mathrm{xL}$ are overexpressed, ${ }^{17}$ it has been subsequently demonstrated that human Noxa interacted with only Mcl-1, but not $\mathrm{Bcl}-2$ or $\mathrm{Bcl}-\mathrm{xL} .{ }^{23,24}$ However, this stringent selectivity is not fully consistent with the observation that overexpression of Noxa was sufficient to induce apoptosis (Figure 7). As shown in Figure 1, only the simultaneous elimination of both $\mathrm{Bcl}-\mathrm{xL}$ and $\mathrm{Mcl}-1$ was sufficient to induce apoptosis, suggesting that the triggering protein(s) need to inactivate both $\mathrm{Bcl}-\mathrm{xL}$ and $\mathrm{Mcl}-1$ to effect mitochondrial damage in HeLa cells. Although the induced Noxa/Bcl-xL interaction seemed weak in the in vitro experiments (Figures 3, 4, 6, and 7), the apoptosis induced by Noxa upregulation (Figure 7) strongly suggests that this interaction happens in vivo, and that Noxa is able to neutralize both $\mathrm{Mcl}-1$ and $\mathrm{Bcl}-\mathrm{xL}$.

How does Noxa induce mitochondrial dysfunction and Bax/Bak activation? Inactivation of both $\mathrm{Mcl}-1$ and $\mathrm{Bcl}-\mathrm{xL}$ may trigger mitochondrial dysfunction through either direct or indirect pathways leading to the activation of Bax/Bak. ${ }^{5-7,27}$ According to the direct activation model, once $\mathrm{Mcl}-1$ and $\mathrm{Bcl}-$ $\mathrm{xL}$ are neutralized, the direct activator $\mathrm{BH} 3$-only proteins, for example, tBid, Bim, or PUMA, may be released and they in turn directly activate Bax or Bak. ${ }^{8}$ Although the knockdown of these three factors individually had no effects in the MG-132induced pathway (Figure 4), it remains possible that all three of these proteins were simultaneously released from $\mathrm{Mcl}-1$ and $\mathrm{Bcl}-\mathrm{xL}$, and either one of them may directly activate Bax/ Bak. On the other hand, the indirect model would suggest that the inactivation of $\mathrm{Mcl}-1$ and $\mathrm{Bcl}-\mathrm{xL}$ by Noxa may cause these two proteins to release Bax or Bak, allowing homooligomerization and activation of Bax/Bak, which would subsequently damage the mitochondria. ${ }^{11,24}$ FRET analysis on the outer membrane of the mitochondria may be used in future studies on these interactions. ${ }^{12}$ Alternatively, Bax/Bak activation may be facilitated by other means, for example, the remodeling of the outer mitochondrial membrane by Drp $1 .{ }^{32}$ It is, therefore, possible that the neutralization of active $\mathrm{Bcl}-\mathrm{xL}$ by Noxa can somehow affect Drp1-mediated membrane remodeling.

Overall, this study used a loss-of-function analysis of the entire Bcl-2 family and a biochemical analysis to define components of the Bcl-2 network and their actions responsible for the mitochondrial pathway following multiple apoptotic stimuli. The approach used and the concept of relevant $\mathrm{Bcl}-2$ network in a given cell should be widely applicable for the study of apoptotic signaling in different cell types in response to various stimuli.

\section{Materials and Methods}

Antibodies and reagents. Antibodies used were as follows: Bmf antibody (Alexis Biochemicals, Lausen, Switzerland, ALX-804-343); Anti-Puma (Sigma, St. Louis, MO, USA, P4743); anti-Bik (Santa Cruz Biotechnology, Inc., Santa Cruz, CA, USA, SC-1710); anti-Bcl-xL (Cell Signaling Technology, Inc., Danvers, MA, USA, 2762 and 2764), anti-Bcl-xL (Sigma, B9429), anti-Mcl-1 (Santa Cruz Biotechnology, Inc., Santa Cruz, CA, USA, S19), anti-Bcl-2 (Santa Cruz Biotechnology, Inc., Sc-509), anti-Bcl-w (Stressgen Biotechnologies, Inc., San Diego, CA, USA, AAP-050), anti-Bax (Santa Cruz Biotechnology, Inc., Sc-493,), anti-Bak (Upstate, Lake Placid, NY, USA. 04-433), Bak Ab-1 (Calbiochem, San Diego, CA, USA, AM03T), anti-Bad (Cell Signaling Technology, Inc., 9292), antiBim (Millipore, Billerica, MA, USA), anti-Noxa (Imgenex, San Diego, CA, USA, IMG349A), anti-Bnip3 (Sigma, B7931), anti-Bid, ${ }^{16}$ anti-FLAG (Sigma, F7415), $\beta$-Actin (Sigma, A5441). TG was purchased from Santa Cruz Biotechnology, Inc. MG-132 was purchased from Sigma. Human recombinant TRAlL was generated as previously described. ${ }^{33}$ 
Cell lines and cell culture. The parental HeLa cells and the pools of HeLa cells stably expressing $\mathrm{His}_{9}-\mathrm{BCl}-\mathrm{xL}$, His $\mathrm{H}_{9}-\mathrm{Mcl}-1$, or the pools of HeLa cells with inducible expression of GFP, Noxa, NoxaL29E, were maintained in DMEM supplemented with antibiotics and $10 \%$ fetal calf serum. Stable cell lines were generated by retroviral infection followed by selection in puromycin.

siRNA transfection. siRNA transfections were carried out in 35-mm culture dishes using $2.0 \times 10^{5}$ cells per plate and DharmaFECT1 transfection reagent (Dharmacon, Inc., Lafayette, CO, USA) in antibiotic-free DMEM supplemented with $10 \%$ serum. All siRNA duplexes used were ON-TARGET plus siRNA pools of four oligos purchased from Dharmacon. The final siRNA concentration used was $20 \mathrm{nM}$ unless otherwise specified. At $60 \mathrm{~h}$ after transfection, cells were either harvested for mRNA and protein analysis, or treated by apoptotic stimuli.

Plasmid construction and retrovirus production. pMaRX-Hisg$\mathrm{Bcl}-\mathrm{xL}$ and $\mathrm{pMaRX}$-Hisg-Mcl-1 were constructed by cloning the human $\mathrm{Bcl}-\mathrm{xL}$ and human Mcl-1 cDNAs into the Xhol-EcoRI-digested pPURO MaRX II retroviral vector (a gift from Dr. Jing Wang, University of Nebraska Medical Center). Human Noxa, NoxaL29E, and GFP were PCR-amplified and cloned into the BamHI and EcoRI sites of the $p$ RetroX-Tight-Puro retroviral vector (Clonetech, Mountain View, CA, USA) following the protocol described above. All retroviruses were produced by transfecting the plasmid DNA of interest into the 293GP packaging cell line.

RT-PCR. RT-PCR was carried out as previously described. ${ }^{26}$

Apoptosis quantification. To quantify apoptosis according to nuclear morphology after siRNA knockdown, cells were transfected with the siRNA oligo of interest and treated with TRAIL, MG-132, or TG $60 \mathrm{~h}$ after siRNA transfection. At different time points after treatment by different drugs, cells were stained with Hoechst 33342 at $1 \mu \mathrm{g} / \mathrm{ml}$ (Molecular Probes, Eugene, OR, USA). Two different viewing areas were randomly chosen for each transfection. Pictures for Hoechst staining were taken for each viewing area, which contained between 300 and 600 cells. The percentage of cells undergoing nuclear condensation was calculated for each viewing area. At least three independent transfection experiments were performed for each oligo of interest.

Nickel beads pulldown. Treated cells were harvested at different time points, and were washed once with PBS. The pellet was re-suspended in EBC buffer (0.5\% NP-40, $120 \mathrm{mM}$ Tris-HCl, pH 7.5, $120 \mathrm{mM} \mathrm{NaCl}, 1 \mathrm{mM}$ EDTA) followed by rotation for $45 \mathrm{~min}$ at $4^{\circ} \mathrm{C}$. The lysate was centrifuged at $22000 \mathrm{~g}$ for $20 \mathrm{~min}$, and the supernatant was incubated with $20 \mu$ lof Ni-NTA agarose (Qiagen, Valencia, CA, USA). After $3 \mathrm{~h}$ of rotation at $4^{\circ} \mathrm{C}$, the beads were washed twice by EBC buffer containing $10 \mathrm{mM}$ of imidazole. SDS loading dye with $250 \mathrm{mM}$ imidazole was used to elute proteins from $\mathrm{Ni}^{2+}$-NTA beads.

Immunoprecipitation of endogenous $\mathrm{Bcl}-\mathbf{x L}$. After washing in PBS, cells were pelleted and resuspended in lysis buffer $(20 \mathrm{mM}$ Tris- $\mathrm{HCl}, \mathrm{pH} 7.4$, $135 \mathrm{mM} \mathrm{NaCl}, 1.5 \mathrm{mM} \mathrm{MgCl}$, $1 \mathrm{mM}$ EGTA, 10\% glycerol, 2\% CHAPS, $0.1 \mathrm{mM}$ PMSF, $5 \mathrm{mg} / /$ pepstatin A, and $10 \mathrm{mg} / \mathrm{l}$ leupeptin). The resuspended cell pellet was rotated gently for $1 \mathrm{~h}$ at $4^{\circ} \mathrm{C}$. The lysate was centrifuged at $22000 \mathrm{~g}$ for $20 \mathrm{~min}$. Supernatant was collected and the concentration of total protein was adjusted to $10 \mathrm{mg} / \mathrm{ml}$ by lysis buffer. In the mean time, $10 \mu \mathrm{l}$ of anti-Bcl-xL antibody (54H6 Cell signaling, 2764) was incubated with $20 \mu$ l of protein A agarose (Santa Cruz Biotech, sc2001) by gentle rotation in $500 \mu \mathrm{l}$ of PBS containing $5 \mathrm{mg} / \mathrm{ml}$ of bovine serum albumin for $2 \mathrm{~h}$ at room temperature. After washing the beads with lysis buffer twice, $800 \mu \mathrm{l}$ of cell lysates were added to the tube containing pre-coupled beads, followed by incubation overnight at $4^{\circ} \mathrm{C}$. The next day, beads were washed with lysis buffer twice and the immunoprecipitates were eluted into $1 \times$ SDS loading buffer by heating to $100^{\circ} \mathrm{C}$ on a heating block. For immunoprecipitation of $\mathrm{Bcl}-\mathrm{xL}$ in lysates from Noxa inducible cells, after the overnight incubation, the protein $A$ agarose beads were washed with lysis buffer containing additional $300 \mathrm{mM} \mathrm{NaCl}$, and proteins were eluted off the beads with IgG elution buffer (Thermo Scientific, Rockford, IL, USA) at room temperature. The elution was immediately neutralized by $1 / 20$ volume of $1 \mathrm{M}$ Tris- $\mathrm{HCl}$, $\mathrm{pH} 9.4$.

Bak activation assay by immunoprecipitation. HeLa cells before and after treatments with TRAIL, TG, or MG-132 were harvested and lysed in CHAPS lysis buffer containing: $50 \mathrm{mM}$ of Tris- $\mathrm{HCl}, \mathrm{pH} 7.4,135 \mathrm{mM}$ of $\mathrm{NaCl}, 1.0 \mathrm{mM}$ of EDTA, $1.5 \%$ CHAPS supplemented with protease inhibitors $(0.1 \mathrm{mM}$ PMSF, $5 \mathrm{mg} / \mathrm{l}$ pepstatin $A$, and $10 \mathrm{mg} / /$ leupeptin). The cell lysates were normalized with lysis buffer to $3.0 \mathrm{mg} / \mathrm{ml}$ of protein concentration. The anti-Bak antibody Ab-1 was coupled to protein A agarose beads and added to $600 \mu$ of the cell lysates. After an overnight incubation at $4^{\circ} \mathrm{C}$, the beads were washed twice with lysis buffer, and the proteins on the beads were eluted into $1 \times$ SDS loading buffer by heating to $100^{\circ} \mathrm{C}$ on a heating block.

Immunoprecipitation of Bak in EBC buffer. To prepare the cell lysate, HeLa cells were lysed by EBC buffer. The lysates were normalized with lysis buffer to $3.0 \mathrm{mg} / \mathrm{ml}$ of total proteins. A volume of $8.0 \mu$ of Bak antibody (Ab-1) was used for immunoprecipitation using the same procedure for the Bak activation assay.

In vitro pulldown by GST-Noxa and GST-Noxa L29E. HeLa cells were transfected with control siRNA or siRNA targeting Noxa. At $48 \mathrm{~h}$ after siRNA transfection, cell lysates $(1.0 \mathrm{mg})$ were incubated with GST, GST-Noxa, or GSTNoxa L29E ( $100 \mathrm{nM})$ at $4^{\circ} \mathrm{C}$ for $2 \mathrm{~h}$, followed by the addition of $10 \mu$ l of Glutathione beads. The mixture was rotated at $4^{\circ} \mathrm{C}$ for another $3 \mathrm{~h}$ and then washed with EBC buffer three times. Beads were then heated to $100^{\circ} \mathrm{C}$ in $50 \mu \mathrm{l}$ of $1 \times \mathrm{SDS}$ loading buffer to elute the bound proteins.

Free Noxa assay by GST-Mcl-1. Whole-cell lysates generated in EBC buffer (total protein $1.0 \mathrm{mg}$ ) were incubated with GST $(100 \mathrm{nM})$ or GST-Mcl-1 $(100 \mathrm{nM})$ at $4^{\circ} \mathrm{C}$ for $1 \mathrm{~h}$. The mixtures were subjected to GST pulldown with gentle rotation at $4^{\circ} \mathrm{C}$ for another hour. After washing with EBC buffer twice, glutathione beads were boiled in $1 \times$ SDS loading solution to elute the bound proteins.

'Mcl-1 free' Noxa with immuno-depletion. HeLa cells were treated with TRAIL (12.5 ng/ml), MG-132 $(10 \mu \mathrm{M})$, or TG $(5 \mu \mathrm{M})$ and harvested at the different time points in EBC buffer. Whole-cell lysates $(1.0 \mathrm{mg})$ were mixed with $5 \mu \mathrm{g}$ rabbit polyclonal anti-Mcl-1 antibodies pre-bound to protein A-agarose beads. After rotation at $4^{\circ} \mathrm{C}$ overnight, the beads were precipitated by centrifugation and washed three times in EBC buffer. The bound and unbound proteins were analyzed by SDS-PAGE and western blotting using Mcl-1 and Noxa antibody.

\section{Conflict of interest}

The authors declare no conflict of interest.

Acknowledgements. This work was supported by the NIH grant GM76237 and a supplement GM76237-04S1. We thank Natalie Targy and Jacquelynn Evans for technical support. We thank Dr. Michel Ouellette for critical reading of the manuscript.

1. Wang X. The expanding role of mitochondria in apoptosis. Genes Dev 2001; 15: 2922-2933.

2. Danial NN, Korsmeyer SJ. Cell death: critical control points. Cell 2004; 116: 205-219

3. Newmeyer DD, Ferguson-Miller S. Mitochondria: releasing power for life and unleashing the machineries of death. Cell 2003; 112: 481-490.

4. Youle RJ, Strasser A. The BCL-2 protein family: opposing activities that mediate cell death. Nat Rev Mol Cell Biol 2008; 9: 47-59.

5. Galonek HL, Hardwick JM. Upgrading the BCL-2 network. Nat Cell Biol 2006; 8: 1317-1319.

6. Chipuk JE, Green DR. How do BCL-2 proteins induce mitochondrial outer membrane permeabilization? Trends Cell Biol 2008; 18: 157-164.

7. Adams JM, Cory S. Bcl-2-regulated apoptosis: mechanism and therapeutic potential. Curr Opin Immunol 2007; 19: 488-496.

8. Kim H, Rafiuddin-Shah M, Tu HC, Jeffers JR, Zambetti GP, Hsieh JJ et al. Hierarchical regulation of mitochondrion-dependent apoptosis by BCL-2 subfamilies. Nat Cell Biol 2006; 8: 1348-1358.

9. Willis SN, Fletcher Jl, Kaufmann T, van Delft MF, Chen L, Czabotar PE et al. Apoptosis initiated when $\mathrm{BH} 3$ ligands engage multiple Bcl-2 homologs, not Bax or Bak. Science 2007; 315: 856-859.

10. Kim H, Tu HC, Ren D, Takeuchi O, Jeffers JR, Zambetti GP et al. Stepwise activation of BAX and BAK by tBID, BIM, and PUMA initiates mitochondrial apoptosis. Mol Cell 2009; 36: 487-499.

11. Fletcher Jl, Meusburger S, Hawkins CJ, Riglar DT, Lee EF, Fairlie WD et al. Apoptosis is triggered when prosurvival Bcl-2 proteins cannot restrain Bax. Proc Natl Acad Sci USA 2008; 105: 18081-18087.

12. Lovell JF, Billen LP, Bindner S, Shamas-Din A, Fradin C, Leber B et al. Membrane binding by tBid initiates an ordered series of events culminating in membrane permeabilization by Bax. Cell 2008; 135: 1074-1084. 
13. Huang DC, Strasser A. BH3-only proteins-essential initiators of apoptotic cell death. Cell 2000; 103: 839-842.

14. Puthalakath H, O'Reilly LA, Gunn P, Lee L, Kelly PN, Huntington ND et al. ER stress triggers apoptosis by activating BH3-only protein Bim. Cell 2007; 129: 1337-1349.

15. Li H, Zhu H, Xu CJ, Yuan J. Cleavage of BID by caspase 8 mediates the mitochondrial damage in the Fas pathway of apoptosis. Cell 1998; 94: 491-501.

16. Luo X, Budihardjo I, Zou H, Slaughter C, Wang X. Bid, a Bcl2 interacting protein, mediates cytochrome $c$ release from mitochondria in response to activation of cell surface death receptors. Cell 1998; 94: 481-490.

17. Oda E, Ohki R, Murasawa H, Nemoto J, Shibue T, Yamashita T et al. Noxa, a BH3-only member of the Bcl-2 family and candidate mediator of p53-induced apoptosis. Science 2000; 288: 1053-1058

18. Fernandez Y, Verhaegen M, Miller TP, Rush JL, Steiner P, Opipari Jr AW et al. Differential regulation of Noxa in normal melanocytes and melanoma cells by proteasome inhibition: therapeutic implications. Cancer Res 2005; 65: 6294-6304.

19. Qin JZ, Stennett L, Bacon P, Bodner B, Hendrix MJ, Seftor RE et al. p53-independent NOXA induction overcomes apoptotic resistance of malignant melanomas. Mol Cancer Ther 2004; 3: 895-902

20. Qin JZ, Ziffra J, Stennett L, Bodner B, Bonish BK, Chaturvedi V et al. Proteasome inhibitors trigger NOXA-mediated apoptosis in melanoma and myeloma cells. Cancer Res 2005; 65 : 6282-6293.

21. Ploner C, Kofler R, Villunger A. Noxa: at the tip of the balance between life and death Oncogene 2008; 27(Suppl 1): S84-S92.

22. Seo YW, Shin JN, Ko KH, Cha JH, Park JY, Lee BR et al. The molecular mechanism of Noxa-induced mitochondrial dysfunction in p53-mediated cell death. J Biol Chem 2003; 278: 48292-48299.

23. Chen L, Willis SN, Wei A, Smith BJ, Fletcher JI, Hinds MG et al. Differential targeting of prosurvival $\mathrm{Bcl}-2$ proteins by their $\mathrm{BH} 3-$ only ligands allows complementary apoptotic function. Mol Cell 2005; 17: 393-403.
24. Willis SN, Chen L, Dewson G, Wei A, Naik E, Fletcher Jl et al. Proapoptotic Bak is sequestered by Mcl-1 and Bcl-xL, but not Bcl-2, until displaced by BH3-only proteins. Genes Dev 2005; 19: 1294-1305.

25. Nijhawan D, Fang M, Traer E, Zhong Q, Gao W, Du F et al. Elimination of Mcl- 1 is required for the initiation of apoptosis following ultraviolet irradiation. Genes Dev 2003; 17: 1475-1486.

26. Lopez H, Zhang L, George NM, Liu X, Pang X, Evans JJ et al. Perturbation of the $\mathrm{Bcl}-2$ network and an induced Noxa/Bcl-xL interaction trigger mitochondrial dysfunction following DNA damage. J Biol Chem 2010; 285: 15016-15026.

27. Wang $Q$, Mora-Jensen $H$, Weniger MA, Perez-Galan $P$, Wolford $C$, Hai $T$ et al. ERAD inhibitors integrate ER stress with an epigenetic mechanism to activate $\mathrm{BH} 3-$ only protein NOXA in cancer cells. Proc Natl Acad Sci USA 2009; 106: 2200-2205.

28. Dai $Y$, Grant $\mathrm{S}$. Targeting multiple arms of the apoptotic regulatory machinery. Cancer Res 2007; 67: 2908-2911.

29. Deng J, Carlson N, Takeyama K, Dal Cin P, Shipp M, Letai A. BH3 profiling identifies three distinct classes of apoptotic blocks to predict response to ABT-737 and conventional chemotherapeutic agents. Cancer Cell 2007; 12: 171-185.

30. Clohessy JG, Zhuang J, de Boer J, Gil-Gomez G, Brady HJ. Mcl-1 interacts with truncated Bid and inhibits its induction of cytochrome $c$ release and its role in receptor-mediated apoptosis. J Biol Chem 2006; 281: 5750-5759.

31. Cuconati A, Mukherjee C, Perez D, White E. DNA damage response and MCL-1 destruction initiate apoptosis in adenovirus-infected cells. Genes Dev 2003; 17 2922-2932.

32. Montessuit S, Somasekharan SP, Terrones O, Lucken-Ardjomande S, Herzig S, Schwarzenbacher $\mathrm{R}$ et al. Membrane remodeling induced by the dynamin-related protein drp1 stimulates bax oligomerization. Cell 2010; 142: 889-901.

33. Pitti RM, Marsters SA, Ruppert S, Donahue CJ, Moore A, Ashkenazi A. Induction of apoptosis by Apo-2 ligand, a new member of the tumor necrosis factor cytokine family. J Biol Chem 1996; 271: 12687-12690.

Supplementary Information accompanies the paper on Cell Death and Differentiation website (http://www.nature.com/cdd) 